\title{
Strategy as Discursive Practice in a Brazilian Public University: A Look under the Perspective of Critical Discourse Analysis
}

\author{
Odemir V. Baêta ${ }^{1}$, Mozar J. Brito ${ }^{1} \&$ Rosália B. Souza ${ }^{2}$ \\ ${ }^{1}$ Departamento de Administração e Economia, Universidade Federal de Lavras, Brazil \\ ${ }^{2}$ Departamento de Letras, Universidade Federal de Viçosa, Brazil \\ Correspondence: Odemir V. Baêta, Rua Sargento Dias, 305 - Queluz, Conselheiro Lafaiete, MG, 36400-000, \\ Brazil. Tel: 55-7525-1400. E-mail: odemirbaeta@posgrad.ufla.br
}

Received: June 12, 2014 Accepted: July 14, 2014 Online Published: September 22, 2014

doi:10.5539/par.v3n2p17 URL: http://dx.doi.org/10.5539/par.v3n2p17

\begin{abstract}
The aim this article a critical discursive analysis of the "management plan" genre of a public institution of higher education, from 2012 to 2015, located in southeast Brazil. The aforementioned plan is inserted in the discursive practice of strategic management, specifically the institutional, bureaucratic management, and is used as an instrument for decision-making. The goal of this analysis will be to discuss the first step of the "management plan", named "organizational policies". We can see that, while elaborating declarative sentences, there is an evaluation of the statements regarding what is to be considered relevant to the institutions by means of the ideological discourse on neoliberal ideals and market behavior. The adoption of market-oriented managerial tools has been a constant in public administration. The public administration looks for bases of organizational practices in the private sphere. This mimicry is still present in the field, and the search for new managerial practices still crosses the imaginaries of the public managers. However, the increasing incorporation of a market-oriented, neoliberal logic, mainly in the adoption of strategic planning, can still be verified. The conclusion presented in this paper serves to foment the debate on the strategies formulated for the Brazilian public service and the methodological applicability of the critical discourse analysis. This meets the emerging need to systematize and integrate distinct theoretical and methodological approaches in the field of organizational studies when strategy is studied as a social and discursive practice.
\end{abstract}

Keywords: critical discourse analysis, Brazilian universities, strategy as discursive practice

\section{Introduction}

By considering that identities, social changes, and discursive elaborations are in constant consolidation and change throughout social actions, we present in this article a critical discursive analysis of the "management plan" genre of a federal institution of higher education, from 2012 to 2015, located in southeast Brazil. The aforementioned plan is inserted in the discursive practice of strategic management, specifically the institutional, bureaucratic management, and is used as an instrument for decision-making. According to what is written within the institutional management plan, the socially built planning methodology was developed from dynamics and flexible phases in the institutional environment through several social and discursive practices, such as interviews, seminars, focus group, lectures, individual orientations, and meetings. The development of the plan is in accordance with the molds defined by the resolution of the University Board of the institution, which seeks to standardize the implementation of strategic planning, ruled by the relevant legislation of Decree 3.860/01 and of Act 10.861, of 14 April 2004, of the National Assessment System for Higher Education (SINAES - "Sistema Nacional de Avaliação da Educação Superior") and of the regulatory provisions expressed in the document.

The goal of this analysis will be to discuss the first step of the "management plan", named "organizational policies". We were able to see, after investigation, that the public university, while building its identity, also naturalizes and institutionalizes the ideological and hegemonic discourses of capitalism. According to Fairclough (1989, p. 85), "the ideology is more effective when its action is less explicit"; we can see "subtleties" within the discourses. Under the approach of Critical Discourse Studies (CDS), in particular of the studies developed by Norman Fairclough $(1989,2001,2003)$, who is considered the greatest representative of CDS (RESENDE \& RAMALHO, 2013), we seek to partially analyze the strategic planning, a typical management tool to private 
organizations, but that, on a institutional situation, is named "management plan" and is currently under a considerable use.

According to Johnson et al. (2007), several segments of the public sector provide services and products to paying customers, in the same way as occurs with the commercial organizations. However, the role of ideology in the development of the strategy of that sector is probably greater than that of the private sector. There is also a great control or influence, directly and/or indirectly, exercised from outside of these institutions, especially from the government. A "commercial" undertaking controlled by the State can have its planning horizon determined more by political questions than by market conditions, apart from the obstacles to the capital investment and financial sources. Because of these reasons, there was a large-scale privatization of companies that were run by the State steel, telecommunications, railroad services, and several others (JOHNSON, et al., 2007). Faced with the aforementioned issues, what we question is: how is the position and the identity of this higher education federal institution ("Instituição Federal de Ensino Superior", IFES) in southeast Brazil being built in its management plan? Why are certain identity constructions still preferred for organizational policies instead of others? The premise of this research is that the organizational policies made for the implementation of the management plan of these IFES can be implicitly loaded with power and ideology relations. Our objective will be to identify and to verify, through critical discourse analysis, how the discursive strategies presented in the organizational policies of the management plan, built collectively by the members of the IFES, can strengthen, transform, or naturalize the hegemonic discourse.

\section{Brazilian Public Administration: Situational Aspects}

According to Andion (2012), functionalist dominance is still very present in public administration. Therefore, the author defends the dialog between different approaches and practices to provide the enrichment to this field. Even though public administration constitutes a multidisciplinary field, a rational orientation dominates to maximize its efficiency and effectiveness. The renowned work Reinventing Government, by Osborne and Gaebler (1994), although not being considered a new paradigm for many scholars in the field of public administration, has influenced new practices in the public sector, having entrepreneurial practices as reference in the basis of the modern bureaucracy. Because of that, from the research of Denhardt (2012), it is possible to see the dominant and current perspective in public administration - the New Public Management -, which has mimetically adopted practices of the private initiative. In this same perspective, Bresser-Pereira (2011) also presents the managerial public administration, focused on the neoliberal practices of professionalization and commoditization in the leading of the public thing. The focus on the public manager was shown to be simplistic by not considering the political dimension and the work conditions in the Brazilian public management, since the power struggle leaves its political role vulnerable after every decision taken. In such context, the Brazilian government incorporates the New Public Management as a marketing insight for the operation of the public sphere, a trend that was responsible for the reform of the State in several countries (PAES DE PAULA, 2005; ABRUCIO, 2007).

The new model that was presented and spread across the country has been responsible for the implementation of several management practices, which are common to the practices of the private initiative, even though it does not always meet the reality of the Brazilian public administration system. Amongst the organizational practices, the more spread and encouraged examples are the strategic planning and the balanced scorecard management tools. Several public organizations have elaborated their organizational policies, building their management plans for the conduction of their administrative activities and, consequently, of their future. Amongst them are the companies of the direct and indirect public management, government enterprises, public agencies, regulatory agencies, and federal universities.

\section{The Management Plan of the IFES}

The Brazilian IFES are part of the federal public administration and present a series of particular characteristics that practically prevent that the contributions from the traditional theories of the private administration be successfully applied to them (ANDRADE, 2003). In this setting, the managers of the IFES - mostly professors are the ones responsible for the administration of the university, adopting management practices, decisions, and actions that allow the achievement of the institutional goals. The managing professor ends up amassing administration activities and academic activities (MARRA \& MELO, 2005). In the case of this IFES, the management plan is one of the instruments that compose the Institutional Planning System ("Sistema de Planejamento Institucional"), structured in four integrated and synergistic main processes: Management Plan, Institutional Development Plan, Institutional Pedagogical Project, and Environmental and Physical Development Plan. 
Based on the strategic planning technique, the management plan seeks to provide a proactive behavior, aiming at the achievement of the institutional goals and, specially, at the establishment of a dynamic between the policies of expansion and the development of the institution. For Meirelles (1995), strategic administration has emerged as a part of the strategic planning, currently considered one of the main management instruments. Strategic planning is one of the most important organizational practices. According to Machado-da-Silva and Vizeu (2007), there is no denying that strategy is an organizational practice. It is in these terms that many authors attribute the decisive moment of propagation and consolidation of the institutional field of the entrepreneur strategy practices to the trend of strategic planning (MOTTA, 2000). According to Matias-Pereira (2009), strategic planning is an essential practice both in the private and public administration because of the benefits it provides to the organizations.

For this article, however, we made a theoretical framework of strategic planning, resorting, for the analysis, to the texts that compose the organizational policies, marked by the first phase of the management plan. This stage includes the elaboration of the mission, the vision, and the institutional goals. According to Kotler, (1980), the mission of the organization must be defined to satisfy a need of the external environment and not to offer some product or service to the market. Nevertheless, for Certo and Peter (1993), the mission is the raison d'etre of the organization. The vision is the interpretation of the external behavior pattern perceiving the social and economical transformations of the globalized world and correlating all of this to the context of specific businesses of the institution. It is about the ability to see, even if it is intuitive, an image of the future to the businesses. If the mission reflects the fundamental business, the vision must revel what it will be in an envisioned future. If the mission shows the raison d'être of the company, the vision aims to project this essence into the future. After the definition of the mission and the vision for the future, the organization focuses on the construction of objectives to be able to act with guidance and fulfill its mission and vision. According to Oliveira (2010), the next phase of the organizational policies is the organizational objective responsible for the guidance of its efforts. In this theoretical approach, the practice of the strategy is no longer understood as an exclusive attribute of positioning and of the performance of the organization, but is to be considered a social and discursive practice, i.e., something that people do. Thus, to understand the practice of the strategy, it is needed to analyze how action standards are associated with the characteristics of the social agents and of the organizational context (JARZABKOWSKI \& SPEE, 2009; WHITTINGTON, 1996, 2004, 2009). To achieve the goal of this research, the organizational policies were analyzed through the CDS model.

\section{CDS: An Analytical Model}

According to Gomes (2011), the critical discourse studies are a theoretical-methodological framework, biased in favor of the social and discursive practices, that serve to denaturalize practices that are said to be universal within the social organization, aiming to assess how the structures of the discourse produce, legitimize, or even question the relations of power. According to Resende and Ramalho (2013, p. 9), the "discourse is a moment of social practice interconnected to other equally important moments". This statement reinforces the importance of the discourse analysis, because discursive samples can transpire the internalization of other moments of the practice in the discourse, such as certain social and ideological relations. This research resorts to the discourse analysis model by Fairclough (2003), which recontextualizes Halliday's Systemic Functional Grammar (SFG) (1991). There are three main types of discourse meanings in the new model by Fairclough (2003), amongst which are the action, the representation, and the identification. For a clipping effect of the types of discourse meanings, the analysis considered only the identification, which considers the construction and the negotiation of identities within the discourse, relating with the identity of Fairclough's CDS model (RESENDE \& RAMALHO, 2013).

Keeping in sight the format and the dimension of the article, we chose to work with the identification meaning only and with the "assessment" category of the aforementioned meaning. We highlight that "every analysis is necessarily incomplete, partial and open to revision" (RAMALHO \& RESENDE, 2011, p. 118) and that the assessments are always subjective, partial, and, because of that, connected to private identification processes. The identification meaning, which is related to the concept of "style", represents the discursive aspects of identities, which serves to identify social actors in texts. Within this meaning, the assessment category is made by evaluative statements and valuation presumptions. The evaluative statements are statements of what is considered desirable or undesirable, relevant or irrelevant. Amongst the evaluative elements, adjectives and evaluative verbs that are grouped in semantic sets of varying intensity, as in the "good/great/excellent" continuum, are subjected to an intensity scale. Regarding the valuation presumptions, they are not marked with transparency of assessment, in which the values are more deeply inserted in the texts, i.e., in the discursive genre. 
The genre has discursive characteristics that are molded in the course of social events. Thus, it is possible to infer that genres are ways to act and to interact and are culturally located, which means to consider distinct discursive ways. Therefore, it is noteworthy that located genres are specific actions of a private practice network: "a kind of language used in the performance of a particular social practice" (CHOULOARAKI \& FAIRCLOUGH, 1999, p. 56). It is through the genre that certain social representations, beliefs, courses of action change, are confirmed; it is how identities are formed. It is important to emphasize that the individuals that have the right to produce any type of genre, i.e., that engage in a discursive practice, also have the possibility to mold concepts, objects, and subject positioning (HARDY et al. 2000).

\subsection{Discursive Genre: Management Plan}

From the perspective of Fairclough, the "management plan" discursive genre is a constituent of a network of social practices, in a specific communicative, social structure, that shows relations of power marked internally, in this case, by the superior leaders of the educational institution. The IFES management plan, which is the object of this analysis, was built in a bureaucratic and institutional practice that produces certain discourses, meanings and construction of subjectivities; it is produced to be consumed not only by the interested in the publicized fact, but also by the society in general. From its sentences, we can verify the premise of normalizing and regulating behavioral actions required by IFES that are published in its management plan. About the level of abstraction, it can be inferred that it is characterized by stability and by rigidity, typical of bureaucratic genres, with little flexibility in its construction, even if it is of tacit knowledge that the social practices present a potential of flexibility and change.

A critical discursive analysis of the management plan genre, or as a subgenre, if part of the Institutional Plan (PDI) is to be considered, comes up against the reality of the research in organizational field: the growing interest for the discursive practices in this context. This confirms a statement by Resende and Ramalho (2013) regarding the fact that EDC has attracted more researchers, not only in the field of Critical Linguistics, but also from other areas of knowledge, such as Applied Social Sciences. According to Alvesson and Karreman (2000), the "linguistic turn", introduced to the social sciences in the decade of 1980, made of the discursive analysis an important element for the organizational studies. The discourse applied to the construction of strategy has been of increasing interest in the last few years in studies that examine the linguistic nature of strategies and the ways the language shapes strategic practices, especially in considering strategy as a social and discursive practice (FENTON \& LANGLEY, 2011; ROULEAU \& BALOGUN, 2011; SPEE \& JARZABKOWSKI, 2011; VAARA, 2010; VAARA et al., 2010, 2004; MANTERE \& VAARA, 2008; HARDY et al., 2000). During the last decade, there has been an increasing focus on the relation between discourse and the organizations (CEDERSTRÖM \& SPICER, 2013). The proliferation of research is demonstrating the rich approach potential of discursive practices applied to strategies. However, at the same time, is shows the necessity of systematizing and integrating diverse approaches to create a general vision of what can happen when discourse is applied to strategy. The approach may allow for new research problems in specific levels and analyses (VAARA, 2010).

Despite its increase, it is argued that the role of the discourse in strategy remains theoretically underdeveloped and empirically little explored (BALOGUN et al., 2009). There are studies with a special focus on power (CARTER et al., 2008). However, to make it possible to understand how power influences the success or the failure of singular strategic initiatives, more studies are necessary (LAINE \& VAARA, 2007). It should be highlighted that power cannot be separated from discourse: the discourse is an instrument, but also an effect of power (FOUCAULT, 1980). Many studies have focused on strategies as discursive practices (MANTERE \& VAARA, 2008; ROULEAU \& BALOGUN, 2011; SPEE \& JARZABKOWSKI, 2011; VAARA, 2010), especially in the everyday practices of strategy managers (JARZABKOWSKI, 2005; WHITTINGTON, 1996) and with the interpretative nature on strategy elaboration. Therefore, strategy is something that the members of an organization "do", not something that the organizations "have" (HENDRY et al., 2010), since a considerable part of the "doing of the strategy" occurs by the language in the form of text and conversation.

The discourse shows how the relations of power shape the constitution of strategy. There are multiple power relations in any society; these relations of power permeate, characterize, and constitute the social body and cannot be established, consolidated, or implemented without the production, the accumulation, the circulation, and the operation of discourse (FOUCAULT, 1980). Discourses are interrelated collections of texts and practices that systematically form the objects of which they speak (HARDY \& THOMAS, 2012).

However, it is important to highlight that the studies of the strategic practice identified how strategists use the discourse in the construction of strategy (LAINE \& VAARA, 2007; ROULEAU, 2005; VAARA et al., 2004), the discourses as narratives (VAARA \& TIENARI, 2011), the discourses as rhetoric (ERKAMA \& VAARA, 2010), 
and the discourses as metaphor. Still, other studies show discursive activities to justify, legitimize, and naturalize actions (VAARA \& TIENNARI, 2002). What is noticed is that the ways that the authors employ to mobilize private discourses for strategic purposes are different (HARDY et al., 2000). Strategy is a discursive construction; the researchers of strategy explore the meanings as a practice and how these meanings play an important role in the way strategies are understood and implemented (FENTON \& LANGLEY, 2011; ROULEAU \& BALOGUN, 2011; VAARA et al., 2010). It is verified, according to Foucault (1980), that every process to build strategies, in addition to the exercise of power, is permeated of increasingly institutionalized discursive practices.

\section{Power and Institutionalized Ideological Discourses}

The social problem chosen for thought is not regarding the generic, regulatory and controller potential of the management plan gender, nor it is about typical attributions of a managing professor, but it is on the attempt to impose a legitimate model of organizational guidelines in a regulatory and disciplined manner. It is verified that some fragments from the texts of the IFES management plan organizational guidelines display social, political, and ideological effects (see Table 1).

Table 1. IFES management plan

\begin{tabular}{c|l}
\hline $\begin{array}{c}\text { Organizational } \\
\text { policies }\end{array}$ & \\
\hline \multirow{3}{*}{ Mission } & $\begin{array}{l}\text { to exercise the integral action of teaching, research, and extension activities, aiming at: the } \\
\text { universalization of quality public higher education, innovation, the promotion of the } \\
\text { institutional development and the promotion of sciences, languages, and arts, as well as at } \\
\text { the formation of citizens with technical, scientific, and human vision, capable of facing } \\
\text { challenges and attending social demands. }\end{array}$ \\
\hline Vision & $\begin{array}{l}\text { the consolidation as an institute of excellence in education, research and extension, } \\
\text { nationally and internationally recognized by the scientific community and society }\end{array}$ \\
\hline \multirow{5}{*}{ Objectives } & $\begin{array}{l}\text { to consolidate and improve the model of management in multicampi universities; } \\
\text { to expand the scientific, intellectual, and cultural production; } \\
\text { to improve the communication between the university and the society, with the support of } \\
\text { media vehicles and digital media; } \\
\text { to broaden the plan of student assistance, aiming at the qualified formation and the reduction } \\
\text { of inequalities, of retention, and of school evasion; } \\
\text { to improve the integrated management politic and people development; } \\
\text { to consolidate the processes of planning and evaluation as decision-making instruments; } \\
\text { to improve the administrative, organizational, financial, and economic efficiency of the } \\
\text { university through the optimization of resources and processes of acquisition, distribution, } \\
\text { application, and control for goods and services. }\end{array}$ \\
\hline
\end{tabular}

According to Leclercq-Vandelannoitte (2011), the organization is a discursive construction under Foucauldian lens that exposes the potential of the Foucault theory for the comprehension of the underlying meaning to this argument, in addition to the answers to its deficiency. The organizations are dynamic in its constitution, and this evolutionary process is continuous and constantly negotiated through power/knowledge relations. Due to linguistic turn in 1980 on social sciences (ALVESSON \& KARREMAN, 2000), the analysis of discourse became an important element for organizational studies. This analysis is still present in studies and has been used to identify the implications of power/control relations in discourses of organizational actors. The study of Foucault often appears in the analyses of organizational discourses and in studies about communication, especially to examine the effects of dominant discourses. This theoretical lens brings the relations between technology and communication, discourse, power, knowledge, discipline and, therefore, articulates the dynamics and political processes, which combine symbolic and material elements in organizational constitution. The social world is organized by rules in specific forms through discursive practices This conception of discourse appears 
in critical language studies that relate to the domination within organizations. The political and social concerns of Foucault (1980) also took the author to recognize the relations of power registered in discourse. Foucault withdrew his incisive affirmation about the discourse being governed by rules, autonomous and with an auto-referent system and by presented genealogy as a complementary approach to explain the control, the selection, the classification and the distribution of discourse production through the relations of power.

\subsection{Discourses and Subjectivity}

The individual identities, with bonds of subjectivity, are built and rebuilt through discourses in the workplace Jackson and Carter (1998) utilize the act of taming to show that work promotes obedience, meekness, and control of members in the organization. Most of the studies verify the power inserted in the organizations through conversation networks that are based on current discursive practices. Thus, language is a form of social control and power. The discourses that reproduce the relations of power are naturally obtained, and these relations can be opaque to the participants. People act in relation to stronger discourses with acceptance, with resistance or commitment (DOOLIN, 2002). In the analysis of discourse, the Foucauldian thought helps to reveal the function of discursive objective formations, the impacts of dominant discourses and the interactions between strong discourses and the local discursive practices. The conceptual framework by Foucault (1980) can be used to explore discourses related to a phenomenon: relation with structures, discipline and control; and individual practices, such as reactions and resistances. The discourses are, simultaneously, locals of domination and resistance, and they are involved in the deconstruction and reconstruction of organizations. Foucault (1980) rejects the "unified vision of the state for a network of institution, practices, procedures and techniques in which the power circulates as strategic relations" (WILLCOCKS, 2004, p. 257). Besides, he encourages the concept of power-knowledge, which means that power produces knowledge. The thought of Foucault (1980) enriches the ontological perspective because it insists in structures, as well as in objectives and in subjective characteristics of social reality. The organizational discourses are combined in a space/time specific physical organization to produce "docile bodies" and, therefore, promote certain forms of control.

According to Ezzamel \& Willmott (2008), the foundation of the Foucauldian power is seen as an innovative complement to establish management analyses. There is no relation of power not related to the constitution of a field of knowledge, nor there is any knowledge that does not presuppose and constitute, at the same time, relations of power. In rational analysis, strategy is designed as a result of impersonal forces, available resources, or the calculation from the rational-decision-maker. However, the strategic analysis as a practice incorporates little consideration of how to get involved in practices that constitute professional as subjects (WHITTINGTON, 1996). The Foucauldian analysis, in contrast, covers how the elements of strategy are mobilized for the construction of practices and actors as strategies in the discourse (KNIGHTS \& MORGAN, 1991). The Foucauldian analysis does not intend to captivate and catalogue the detailed aspects of strategy elaboration, but how the strategists think, talk, react, interact, feel touched, embellish, and politicize (JARZABKOWSKI, 2005). It is concerned with valuation as a strategy, i.e., how the discursive practice works to build the operationalized professional world.

\subsection{Strategy as Social Practice}

Strategic management can be considered a social practice and, in this sense, the strategy involves routines, standards, and rules in which both allow and limit the actions of the strategist/subject, just as they limit the possible action field. Taking an overall approach of strategy as something that companies have or not, strategy is seen as an activity in which the individuals realize and interact in physical and social contexts (WHITTINGTON, 2004). In the development of a discursive version of strategy as a practical approach, some researchers underline the influence of discursive practices in subjectivity and the behaviors of organizational members. The seminal Foucauldian analysis considers strategy as a discourse, which is a set of ideas and practices that condition our ways of relating with our way of acting on private phenomena (KNIGHTS \& MORGAN, 1991). Firstly, it is necessary to see the strategic practices as a part of a great power arena and, then, as a body of knowledge and discourse. In the first place, while part of a power field, strategic practices appear as a result of multiple conditions and random events. Secondly, in the condition of field of knowledge, strategic management can be seen as a heterogeneous set of discursive and material practices. These practices are governed by specific functions that partially structure what can be read, said, and done about reality.

\section{Discussions}

We were able to verify a legitimatizing identity from the organization guidelines, regarding not only the process of repressive isomorphism, when there are explicit orientations from hierarchically superior organs on the elaboration of the management plan of the IFES, but also the legitimacy through the use of a management tool 
that is openly accepted in the private sector. We can see that, while elaborating declarative sentences, there is an evaluation of the statements regarding what is to be considered relevant to the institutions by means of the ideological discourse on neoliberal ideals and market behavior. In one of the institutional goals, such as "to consolidate and improve the model of management in multicampi universities; to expand the scientific, intellectual, and cultural production; to improve the communication between the university and the society", we ask: which management model would this be if we were to consider a federal public institution with its social function? Would it be based on New Public Management, inspired on neoliberalism?

In its mission, the institution is said to be able to "face the challenges and meet the demands of society"; however, what we verify in the very same statement is that the institution chooses its priority in the discourse when it puts development in first plan, in detriment of the sciences, leaving languages and arts at a second plan; likewise, it seeks to raise citizens with a technical and scientific view, relegating the humanistic formation to a third plan. For a public higher education institution to have "the development of languages and arts" as its mission and, at the same time, not having more than $11 \%$ of its graduation programs and $25 \%$ of its under-graduation programs in the fields of humanities and social sciences, there is a resonance regarding the governmental exchange program "Ciências sem Fronteiras" ("Sciences without Borders"), which excludes these areas of knowledge based on the fact that they do not meet the strategies of the current government. We still ask ourselves what would be considered strategic for the federal government and for the public university regarding the formation of its recent graduates. How can we define the preferable fields and strategies? Following this logic, are we to meet the necessities of the society or the current emergences of the market? For its vision, the institution also demonstrates greater interest in being nationally and internationally recognized by the academic community, to only subsequently be recognized by the society. It also works with a market-oriented idea of projecting visibility by means of its communication tools. It is spoken of broadening the scientific production first to then foment intellectual and cultural production. The choice of the verb "ampliar" ("expand", "broaden") demonstrates the quantitative worry and the productivist logic, since terms such as "enhancement" or "quality" regarding this production are never mentioned.

What is seen in the management practice adopted by the analyzed IFES is an institutionalized tendency that sustains a usage that oriented more by legitimacy and less by performance. Such legitimacy disseminates already interiorized and socially accepted models, which would be no different with strategic planning. What occurs in managerial practices adopted by public organizations is an institutional bias that underpins their use, the more legitimacy than the performance. Such legitimacy propagates models already internalized and socially accepted, which would be no different with strategic planning. In this institutional field, Brazilian IFES not limited only to exchange materials and resources, but there is a symbolic, subjective exchange of experiences and practices propagated by the legitimacy of its uses. All these experiences result in an increasingly homogeneous institutional environment. Public universities tend to seek an isomorphism that is more institutional than it is competitive, despite its organizational guidelines demonstrating a marketed-oriented logic instead of having an institutional orientation. However, fact is that the institution aims at guaranteeing the legitimacy of its practices. One of the mechanisms that promote its environmental changes is repression, for the public sector is always subjected to political influences and to constant pressures to meet a given institutionalized or ideological standard. Nevertheless, the repressive process does not come solely from legislation, but also from public bodies; in the case of public universities, it is those organs that keep some type of hierarchic relation or some degree of dependence. The adoption of market-oriented managerial tools has been a constant in public administration; many public administrators are pressured to adopt these tools with the objective of reinventing the approaches or practices that are considered inefficient. However, this action is not always considered positive by researches of the field, since it would be necessary to verify the particularities of Brazilian public organizations, which still carry much bureaucracy and patrimonialism; the implementation of managerial practices would call for a different logic.

The discourse that states that public universities are to obey the current legislation is the same applied to every public body; the need to fit certain operationalization standards and some rules that coordinate the organizational field are elements that fundament and evince a repressive isomorphic process and its relations of power. This organizational homogenization is imposed, amongst other reasons, by regulatory governmental bodies. It is possible to determine that there is a search for normative conformity. Therefore, the institutional pressures to regulate public universities according to the standards and models established by the old Ministry of Public Administration and Brazilian State Reform (MARE) configure an isomorphic process in the Brazilian public system. The process of institutionalization in universities promotes, increasingly, organizational changes are substantial and a high degree of formalization for them to continue working. Institutional environments of 
Brazilian IFES are conditioned by an environment of rigid and supported regulation specifically prescribed by determinations by regulatory and supervisory agencies of the federal standards. Therefore, if, on the one hand, public companies need to adapt to the regulation of the sector, induced by institutionalized norms and legislation, we can verify, on the other hand, that, in addition to power, this process is mediated by the mimicry present in Brazilian public administration as a whole. Public organizations seek institutional isomorphism, since what they want is actually to ensure the legitimacy of their practices. One of the mechanisms that promote their environmental changes is coercive, because the public sector is always subject to political influence and constant pressures to meet either institutionalized pattern.

The possibility of a homogenization process in the Brazilian public service will serve as a parameter for managerial practices adopted by the private sector to be copied. The adoption of mimetic changes is always comprehended and mediated by managers (or equivalent positions) who find it necessary to adopt them. It is known that the professional support of upper level technicians in Brazilian IFES, career civil servants with an academic background in Business Administration or related fields in the construction of strategic planning allows more legitimacy in this field, which implies credibility and institutional support. Thus, in spite of the copy, the mimicry is never perfect; it is always subjected to alterations in the course of time. The short analysis of this framework - organizational guidelines for the management plan - allowed us to verify that the discourse constructed from the social representation of the university is first to attempt legitimacy and then to play an official role on social inclusion. What was made evident through the management plan, especially regarding the guidelines, was a propitious environment to act and consolidate the identity of the university. The management plan is part of a network of social practices, which integrates a specific social, communicative structure and constitutes the relations of power institutionalized by the university.

It is possible to see that language acts in the managerial plan as a way of maintaining or consolidating certain sociopolitical representations regarding the institution. The choice of the evaluative constructions, according to Fairclough (2003), is important not only to understand the constructions of action (genres), but also the constructions of identity, since the text is relative to attitudes and appreciations. There is a required construction with a great degree of obligation, demonstrating a desirable model of institution. The actions constructed and considered ideal for the guidelines, according to a neoliberal model, are desirable for the institution that defines its model through a market-oriented, neoliberal discursive construction. Every statement is produced by an assertive, i.e., there are no questions, exclamations, or imperatives that could allow for a dialogical construction; this allows for a monological construction, which is affirmative and definitive, and does not permit contestation. In other words, there are declarations that impose how institutionalized actions are to be constructed though typical hegemonic evaluations.

\section{Conclusion and Recommendations}

The organizational guidelines serve to justify the exercise of power by those who have it. They produce identity meanings, which makes servants relate to the actions to be executed. The institutionalized objectives follow the tendency of the new public management of using experts in the area of planning to strategically reach the objectives and, consequently, the goals and actions for a public that is not "trained" in the field: the faculty members. The institutional environments of federal public universities are conditioned by a strict environment and aided specifically by determinations prescribed by regulatory organs of the Union. What we see is that the process of institutionalization of the IFES increasingly promotes substantial organizational changes of a high regulatory degree. However, it is worthy noticing that this process of institutionalization has implications for a greater homogenization of norms and practices, therefore seeking to reach and fit the models and standards established, as well as aiming at the legitimacy of its organizational context. These changes lead to symbolic elements that attest the meanings of a discourse in determined changes that surpass logical requisitions, for they are about alterations on a institutional level. These changes are not to meet the demands of the market, but to fit the conformities demanded by the supervisory and regulatory organs that accompany the activities of public administration in the country. It is precisely this regulatory adequacy that has determined the transformations in the practice of creating management plans for Brazilian IFES. These changes are not taking place by their own, but are happening as an integrating part of an institutional conjuncture of the organizational field for the Brazilian state reform, implicitly carrying a neoliberal discourse. There are governmental interests that meet the homogenization of the administrative practices in Brazilian public bodies, aiming at the standardization of the planning and management processes.

These changes suggest a redesign of the new habits, in order to apprehend new routines in managerial practices of Brazilian IFES. The internalization of the copied practices may influence the policies of the organization involving the existing organizational structures. These practices are not warranty of efficiency, for their 
organizational structures are highly institutionalized and influence their daily actions, therefore disregarding some necessary actions. Determined managerial practices are regulated as functioning models by certain external public bodies; in the case of the IFES, they are under the responsibility of the Instituto Nacional de Pesquisas Educacionais (INEP, "National Institute for Educational Research") and of the Ministry of Education (MEC) itself. It is also a conditioning for the institutional environment and for the governmental structures that coordinate their applicability. The government determines the norms and the standards for the implementation of the management plan, therefore inducing the isomorphism in its organizational changes. This regulatory adequacy seeks to transform the most well-known public institutions. The meeting of these federal norms is a significant source of changes for Brazilian IFES.

The organizational guidelines of the management plan for the analyzed university confirm that the ideology is not always visible, given it subtlety in the discursive construction. These discursive practices, due to the fact they are present in texts of the public administration, evince a greater presence of the ideological and hegemonic role and the repressive control by part of the hierarchically superior public bodies. Given the still-functional predominance in the administrative activities of the public sector, the dialog between theories on Linguistics and Sociology are important for the enrichment of the discussions and the debates in the field of public administration. The public administration looks for bases of organizational practices in the private sphere. This mimicry is still present in the field, and the search for new managerial practices still crosses the imaginaries of the public managers. However, the increasing incorporation of a market-oriented, neoliberal logic, mainly in the adoption of strategic planning, can still be verified. The discussion presented in this paper serves to foment the debate on the strategies formulated for the Brazilian public service and the methodological applicability of the critical discourse analysis. This meets the emerging need to systematize and integrate distinct theoretical and methodological approaches in the field of organizational studies when strategy is studied as a social and discursive practice. These investigations are not very empirically explored and still show a need for development and theoretical discussion.

\section{References}

Abrucio, L. F. (2007). Trajetória recente da gestão pública brasileira: um balanço crítico e a renovação da agenda de reformas. Rev. Adm. Pública, Edição Especial Comemorativa, 2, 67-87. http://dx.doi.org/10.1590/S0034-76122007000700005

Alvesson, M., \& Kärreman, D. (2000). Varieties of discourse: on the study of organizations through discourse analysis. Human Relations, 53(9), 1125-1149. http://dx.doi.org/10.1177/0018726700539002

Andion, C. (2012). Por uma Nova Interpretação das Mudanças de Paradigma na Administração Pública. Cadernos EBAPE. BR-FGV, 10(1). http://dx.doi.org/10.1590/S1679-39512012000100003

Andrade, A. R. (2003). Gestão Estratégica de Universidades: Análise comparativa de instrumento de planejamento e gestão. Paper presented at the XXVII ENANPAD - Atibaia-SP.

Balogun, J., Jacobs, C., Jarzabkowski, P., Mantere, S., \& Vaara, E. (2009). Strategy as discourse: Its significance, challenges and future directions. Journal of Management Studies, 46.

BRASIL, Decreto $\mathrm{n}^{\circ} 3.860$, de 9 de julho de 2001. dispõe sobre a organização do ensino superior, a avaliação de cursos e instituições, e dá outras providências. Diário Oficial [da] República Federativa do Brasil, Poder Executivo, Brasília, DF, 09 jul. 2001. Retrieved from http://www.lexml.gov.br/urn/urn:lex:br:federal:decreto:2001-07-09;3860

BRASIL, Lei n 10.861, de 14 de abril de 2014, institui o Sistema Nacional de Avaliação da Educação Superior SINAES e dá outras providências. Diário Oficial [da] República Federativa do Brasil, Poder Executivo, Brasília, DF, $14 \quad$ abr. $2014 . \quad$ Retrieved $\quad$ from http://www.planalto.gov.br/ccivil_03/_ato2004-2006/2004/lei/110.861.htm

Bresser-Pereira, L. C. (2011). Construindo o Estado republicano: democracia e reforma da gestão pública. São Paulo: FGV.

Cederström, C., \& Spicer, A. (2013). Discourse of the real kind: A post-foundational approach to organizational discourse analysis. Organization, $0(0), 1-28$.

Certo, S. C., \& Peter, J. P. (1993) Administração estratégica: planejamento e implantação da estratégia. São Paulo: Makron Books.

Chouliaraki, L., \& Fairclough, N. (1999). Discourse in late modernity. Rethinking critical discourse analysis. Edinburg, University Press. 
Denhardt, R. B. (2012). Teoria da Administração Pública (6th ed.). São Paulo: Ed. Cen. Learning.

Doolin, B. (2002). Enterprise discourse, professional identity and the organizational control of hospital clini cians. Organization Studies, 23, 369-390. http://dx.doi.org/10.1177/0170840602233003

Erkama, N., \& Vaara, E. (2010). Struggles over legitimacy in global organizational restructuring: A Rhetorical perspective on legitimation strategies and dynamics in a shutdown case. Organization Studies, 31(7), 813-839.

Ezzamel, M., \& Wllmott, H. (n. d.). Strategy as Discourse in a Global Retailer: A Supplement to Rationalist and Interpretive Accounts. Organization Studies, 29(2), 191-217. http://dx.doi.org/10.1177/0170840607082226

Fairclough, N. (1989). Language and Power. London: Longman.

Fairclough, N. (2001). Discurso e mudança social. Trad. (Org.) Izabel Magalhães. Brasília: UnB.

Fairclough, N. (2003). Analysing discourse: textual analysis for social research. London: Routledge.

Fenton, C., \& Langley, A. (2011). Strategy as practice and the narrative turn. Organization Studies, 1-26.

Foucault, M. (1980). Vigiar e Punir (32th ed.). Petrópolis: Vozes.

Gomes, M. C. A. (2011). Das questões ideológicas e éticas: uma análise discursiva crítica do gênero edital da guarda municipal-RJ. In C. C. S. Paes, \& M. S. S. Melo (Eds.), Estudos discursivos em foco: práticas de pesquisa sob multiplos olhares. Ed. UFV. Viçosa.

Gonçalves, C. A., Filho, C. G., \& Neto, M. T. R. (2006). Estratégia Empresarial: o desafio das organizações. São Paulo: Saraiva.

Hardy, C., \& Thomas, R. (2012). Strategy, discourse and practice: the intensification of power. Journal of Management Studies. Blackwell Publishing Ltd and Society for the Advancement of Management Studies. http://dx.doi.org/10.1111/joms.12005

Hardy, C., Palmer, I., \& Phillips, N. (2000). Discourse as a strategic resource. Human Relations, 53(9), 7-28. http://dx.doi.org/10.1177/0018726700539006

Jackson, N., \& Carter, P. (1998). Labour as dressage. In A. McKinlay, \& K. Starkey (Eds.), Foucault, management and organizational theory (pp. 49-64). London: Sage.

Jarzabkowski, P. (2005). Strategy as practice: an activity based approach. London. Sage.

Jarzabkowski, P., \& Seidl, D. (2008). The Role of meetings in the social practice of strategy. Organization Studies. Sage Publications, 29(11), 1391-1426. http://dx.doi.org/10.1177/0170840608096388

Jarzabkowski, P., \& Spee, A. P. (2009). Strategy-as-practice: a review and future directions for the field. $\begin{array}{lllll}\text { International Journal of } & \text { Management }\end{array}$ http://dx.doi.org/10.1111/j.1468-2370.2008.00250.x

Johnson, G., Scholes, K., \& Whittington, R. (2007). Explorando a estratégia corporativa (7th ed.). Porto Alegre. Ed. Bookman.

Knights, D. (1990) Subjectivity, power and the labour process. In D. Knights, \& H. Willmott (Eds.), Labour process theory (pp. 88-103). London: Macmillan.

Knights, D., \& Morgan, G. (1991). Strategic Discourse and subjectivity: towards a critical analysis of corporates $\begin{array}{llll}\text { strategy in } \quad \text { organizations. } & \text { Organization }\end{array}$ http://dx.doi.org/10.1177/017084069101200205

Kotler, P. (1980). Marketing. São Paulo: Ed. Compacta.

Laine, P.-M., \& Vaara, E. (2007). Struggling over subjectivity: A discursive analysis of strategic development in an engineering group. Human Relations, 60(1), 29-58. http://dx.doi.org/10.1177/0018726707075279

Lecclercq-Vandelannoitte, A. (2011). Organizations as Discursive Constructions: A Foucauldian Approach. Organization Studies, 32(9), 1247-1271, Sage Publications. http://dx.doi.org/10.1177/0170840611411395

Machado-Da-Silva, C. L., \& Vizeu, F. (2007). Análise Institucional de práticas formais de estratégia. RAE, 47(4), $89-100$.

Mantere, S., \& Vaara, E. (2008). On the problem of participation in strategy: A critical discursive perspective. Organization Science, 19(2), 341-358. http://dx.doi.org/10.1287/orsc.1070.0296

Marra, A. V., \& Melo, M. C. O. L. (2005). A Prática Social de Gerentes Universitários em uma Instituição 
Pública. $R A C, 9(3), 9-31$.

Matias-Pereira, J. (2009). Manual de Gestão Pública Contemporânea. São Paulo: Ed. Atlas.

Meirelles, A. M. (1995). O planejamento estratégico no Banco Central do Brasil e a viabilidade estratégica em uma unidade descentralizada da autarquia: um estudo de caso. (unpublished master thesis), CEPEAD/FACE/UFMG, Belo Horizonte: UFMG.

Motta, P. R. (2000). Gestão contemporânea: a arte e a ciência de ser dirigente (11th ed.). Rio de Janeiro: Record.

Oliveira, D. P. R. de. (2010). Planejamento estratégico: conceitos, metodologias e práticas. São Paulo: Atlas.

Osborne, D., \& Gaebler, T. (1994). Reiventando o governo: como o espirito empreendedor está transformando o setor público (3rd ed.). Brasília: MH Comunicações.

Paes De Paula, A.P. (2005). Por uma Nova Gestão Pública. Rio de Janeiro: FGV.

Ramalho, V., \& Resende, V. M. (2011). Análise de discurso (para a) crítica: o texto como material de pesquisa. Campinas. Ed. Pontes.

Resende, V. M., \& Ramalho, V. (2013). Análise de discurso crítica. Ed. Contexto (2nd ed.). São Paulo.

Rouleau, L. (2005). Micro-practices of strategic sensemaking and sensegiving: How middle managers interpret and sell change every day. Journal of Management Studies, 42, 1413-1443. http://dx.doi.org/10.1111/j.1467-6486.2005.00549.x

Rouleau, L., \& Balogun, J. (2011). Middle managers, strategic sensemaking, and discursive competence. Journal of Management Studies, 48(5), 953-983. http://dx.doi.org/10.1111/j.1467-6486.2010.00941.x

Spee, P., \& Jarzabkowski, P. (2011). Strategic planning as communicative process. Organization Studies, 1-29. Retrieved from http://oss.sagepub.com/content/early/2011/07/21/0170840611411387

Vaara, E., \& Tienari, J. (2002). Justification, legitimization and naturalization of mergers and acquisitions: A critical discourse analysis of media texts. Organization, 9(2), 275-303. http://dx.doi.org/10.1177/1350508402009002912

Vaara, E., \& Tienari, J. (2011). On the narrative construction of MNCs: An antenarrative analysis of legitimation and resistance in a cross-border merger. Organization Science, 22(2), 370-390. http://dx.doi.org/10.1287/orsc.1100.0593

Vaara, E., Kleymann, B., \& Seristo, H. (2004). Strategies as discursive constructions: the case of airline alliances, Journal of Management Studies, 41(1), 1-35. http://dx.doi.org/10.1111/j.1467-6486.2004.00419.x

Whittington, R. (1996). Strategy as Practice. Long Range Planning, 29(5), 731-735. http://dx.doi.org/10.1016/0024-6301(96)00068-4

Whittington, R. (2004). Estratégia após o modernismo: Recuperando a prática. Revista de Administração de Empresas, 44(4), 44-53.

Whittington, R. (2009). Completing the Strategy Research. Organization Studies, 27(5), 613-634. http://dx.doi.org/10.1177/0170840606064101

Willicocks, L. (2004). Foucault, power/knowledge and information systems: Reconstructing the present. In J. Mingers, \& L. Willcocks (Eds.), Social theory and philosophy for information systems (pp. 238-296). Chichester: Wiley.

\section{Copyrights}

Copyright for this article is retained by the author(s), with first publication rights granted to the journal.

This is an open-access article distributed under the terms and conditions of the Creative Commons Attribution license (http://creativecommons.org/licenses/by/3.0/). 